\title{
Corporate Social Responsibility; Mutual Expediency of Transnational Companies and Developing Countries
}

\author{
Turkana Allahverdiyeva \\ Instituto Politecnico de Viana do Castelo (IPVC), Viana do Castelo, Portugal \\ Email: Turkana.allahverdi@gmail.com \\ Received 26 January 2016; accepted 24 April 2016; published 27 April 2016 \\ Copyright (C) 2016 by authors and Scientific Research Publishing Inc. \\ This work is licensed under the Creative Commons Attribution International License (CC BY). \\ http://creativecommons.org/licenses/by/4.0/ \\ (c) (i) Open Access
}

\section{Abstract}

The Corporate Social Responsibility (hereafter CSR) concept of Transnational Corporations (hereafter TNCs) is beneficial from many aspects for the societies living in host countries and their governments. Some researchers claim that it has no benefit for TNCs rather than being waste of time, energy, labor and money; the only party enjoying CSR is developing countries. However, the paper clarifies that both parties reap benefits from CSR programs and give away something in return hence, the aim of this paper is to take up several issues in the hope of clarifying above-mentioned controversy and misapprehension and discussing gains and losses for both parties-TNCs and developing nations. As a result, the paper has revealed that actually it is not TNCs who lose money, labor and time but in fact it is developing countries that give more but get less in return with these CSR programs. These findings establish better understanding of CSR, TNC policy in developing countries and a base for future researches.

\section{Keywords}

Corporate Social Responsibility, Corporate Ethics, Business Ethics, Developing Countries, Transnational Corporations

\section{Introduction}

Since the beginning of 2000s, forgery, corruption, violation of human rights, violation of labor code and some other kind of illegal acts of corporates appealed attention of the world. Transnational corporations take start to be criticised all over the world and more and more questions about ethical responsibilities of TNCs are put forward by the community, media and researchers of the field. If we take into consideration that only 47 out of 100 
biggest economies in the world are nation states, and 53 are TNCs [1], then it becomes clearer to understand the importance of them in the modern capitalism system. Similarly as they get bigger and stronger, the debate over Corporate Social Responsibility grows warmer and it becomes more important to do a comprehensive research on it. Since they prefer to locate their manufacture process in developing countries, the concept of CSR is mostly conducted in these nations. The question arises that who gains and loses from CSR programs both sides or one of them? What are the interests of TNCs to conduct CSR programs? What do developing countries gain and lose from such programs? These questions made us to conduct a research to understand CSR policy of TNCs better in developing countries. We also decide to focus on specifically developing countries, since they are the countries where TNCs' affiliates are located and conduct these programs. Discussions usually take us to the result that TNCs lose and Developing Nations gain, however the arguments in this paper presents reach the result that in fact Developing Nations do not gain more in return what they give.

To start the discussion it is important to understand the meaning of CSR first. There are several definitions in the literature and according to the United Nations Conference on Trade and Development (UNCTAD) definition, "Transnational corporations (TNCs) are incorporated or unincorporated enterprises comprising parent enterprises and their foreign affiliates. A parent enterprise is defined as an enterprise that controls assets of other entities in countries other than its home country, usually by owning a certain equity capital stake" (Definitions and Sources, UNCTAD, 2007). CSR notion has produced an array of various definitions since its emergence in the history. The history of CSR goes back to Adam Smith's book "the Wealth of Nations", where he defines the basic responsibility of firms to maximize profits for stakeholders and to provide products and labor for the society [2]. Unconditionally it is very basic and simplified definition of CSR and it follows many other discussions and new definitions of CSR in the literature. Since 1930, many articles have been written on it trying to educate businessmen on social responsibility. As time goes on, discussions on CSR form two types of schools, those who is in favor of basic responsibilities within the boundary of law and basic ethical responsibilities [3] [4] and those who have suggested more social obligations of TNC towards society [5] [6]. TNCs operate in other countries mostly in developing countries (DC) and do business which may sometimes cause side effects. Consequently related with these activities there is a hot debate that TNCs should take responsibility of their harmful and environmentally hazardous operations. These huge farms use malignant antibiotics to fatten animals, use pesticide killers which also kill honeybees, emit harmful gases into the air and consequently damage and pollute environment. The question arises who should take the responsibility of these activities? Business firms themselves, government or public? Even in 1967 Davis was asking the question of "What does the businessperson owe society?" [7] Besides environmental duties, TNCs are assumed having some other duties such as protecting and promoting human rights and moral labor division as part of the CSR activity in the host country they are located in. In 1979, Archie B. Caroll defined CSR in his article as follows: "The social responsibility of business encompasses the economic, legal, ethical, and discretionary (philanthropic) expectations that society has of organizations at a given point in time” [8]. Later, scholars divide these responsibilities into four parts from most important to the least one in the pyramid shape that TNCs have to obey, economic responsibility, legal responsibility, ethical and philantropic responsibility [9]. The very last research of CSR was presented by A. Dalshrud from Norwegian University of Science and Technology in 2006 has offered five dimensions of CSR; environmental dimension (a clear environment), the social dimension (contribute to a better society), the economic dimension(contribute economic development), the stakeholder dimension (interaction with their stakeholders), the voluntariness dimension (based on ethical values) [10].

Summarizing above, ever since the debate over CSR commenced, different types of approaces towards it were articulated by scholars, some against and some for. While on one hand, it is stood up for being useful of CSR for TNCs, on the other hand the favours for TNCs are partly rejected claiming they are waste of time, money and labor. From the point of Developing countries, more contradictory opinions have been announced, and the paper is going to discuss both sides and draw a conclusion.

\section{Corporate Social Responsibility; What Are Expediancies for TNCs?}

Some classical economists argue that TNCs do not/should not need CSR programs, since they slow down their development, however this part of the essay is attempting to clarify the benefits of CSR for the TNCs. By some economists, it is believed that having the concept of CSR in the corporate is mutual beneficial for TNCs and developing countries. TNCs do not donate money or do not launch philanthropy in developing nations just for humanitarianism, it is two sided win-win game for both TNCs and developing countries. Hereby, according to 
Archie B. Carroll's global CSR pyramid (2004), TNCs have these basic responsibilities: “1) Make a profit consistent with expectations for international businesses; 2) Obey the law of host countries as well as international law; 3) Be ethical in its practices, taking host-country and global standards into consideration; 4) Be a good corporate citizen, especially as defined by the host country's expectations”. The first point of the responsibility is consistent with A. Smith's basic responsibility, which includes TNCs first focus on making profit and maximizing it for both development of the society, for its stakeholders and in the broad sense for the sustainable advancement of the economy. Firstly by bearing this responsibility, TNCs will also mutually increase its life span and sustainability.

Second point is the legal obligations of all TNCs that should be obeyed. Here we can refer to Tom Donaldson's fundamental human rights which are regarded as moral minimums such as freedom from torture, a fair trial, physical security, speech and association, and subsistence [11]. Second benefit, complying with the universal ethics and human rights, will also keep TNCs apart from criticism of human rights defenders.

However third and fourth points are neither obligatory nor based on law. They are basically phylantropic or volunteer issues that TNCs strive to do for their own good. Third gain of TNCs is having a stronger comparative advantage than others, since they attract more respect and positive image from the world community and the society in host country. A good example of this is Total oil company's ecological environmental program, which increases its credibility among stakeholders and sustainability in the community. "Two of its European rivals, shell and BP, are also making ethics a focal point of their environmental practices” [12]. Thus, complementing such global standards TNCs obtain sympathy in the host country.

The fourth point of being good example of corporate citizen includes seven other philanthropistic and sympatetic steps that DeGeorge mentioned in his book; 1) MNCs should do no intentional, direct harm; 2) produce more good than bad for the host country; 3) contribute to the host country's development; 4) respect human rights; 5) pay their fair share of taxes; 6) respect the local culture; 7) and cooperate with the host government in developing ethical background institutions (e.g., health and safety standards) [13]. Fourth gain of TNCs by bearing the above-mentioned responsibilities in the host countries, they will lighten the pressure from the governments and their social public, fifth, they will increase their reputation throughout the world, and "reduce political risks at the lower costs" [2]. Complying human rights, paying taxes and sometimes donating charity to the host country will avail the TNCs gaining legitimacy, accessing to the market and decision-makers and even avoid regulations.

The last but not least benefit of CSR programs in developing nations are that by locating and processing in these countries, TNCs earn more, manipulate more, be stronger and have competitive advantage since usually they do not have much competitors in contrast with the developed countries. With CSR programs, they extend their existence in the host country since they get sympathy of the government and society.

\section{Arguments against CSR Concept of TNCs}

As A. Carroll and K. Shabana emphasized in their article in 2009 [14], the arguments against the concept of CSR goes back to the classical economic argument written by Milton Freidman in 1962. The first argument against CSR is that he basically was saying the social problems of the society is not work of the businessmen, it should be solved in the free market and in case it cannot be solved then government and legislative bodies should intervene the case but business firms [15]. M. Friedman was noting in his article published in 1970 "Businessmen who talk this way are unwitting puppets of the intellectual forces that have been undermining the basis of a free society these past decades" [3]. For him, CSR is apparently violation of free market or Marketplace Responsibility.

Secondly, businessmen who are the corporate executives of the company has other crucial responsibilities such as making money as much as possible, gaining profit and developing the company, i.e. doing a real business in the framework of law, legislation and business ethics. Doing the opposite "harms the foundations of a free society" [3]. Third argument against CSR is that as David Vogel professor of California University articulated in his article that one can find some records for TNCs have advanced successfully with good CSR performance, and those have weakened with poor CSR arguments. However we can also find more records that TNCs with poor CSR program have perfectly done its business and rewarded its stakeholders, and those with perfect CSR programs have failed to develop [16]. D. Vogel is trying to clarify here that the CSR program of the corporate has nothing to increase the profit while TNC's main responsibility is to maximize profit. For instance, "Starbucks provides a good example of the limited importance of CSR to financial performance. The firm en- 
joys a strong CSR reputation due to its generous labour policies and its commitment to improve the earnings and environmental practices of coffee growers in developing countries. Yet since the beginning of 2008, its shares have recently declined nearly 50\% (at last glance the S\&P 500 is down "only" 36\%). The stock's disappointing performance has absolutely nothing to do with CSR: It is entirely due to the firm's overexpansion and, most recently, the increasing unwillingness of consumers to pay as much for a cup of coffee” [16]. Fourth argument is that businessmen in corporates might be successful people and the corporates themselves might be the best in doing business, but it does not mean that they have other social and environmental skills that cure the society's problems. Simply the people in the corporations are not well-trained or well-educated for social programs and the TNCs do not have necessary equipment for social responsibilities [17].

\section{CSR in Developing Countries-Gains and Losses}

In developing countries, development of Small and Medium Enterprises (SME) play a crucial role in the improvement of the whole economy of the country, integration to the world economy and in the process of democratization, deregulation, and liberalization of the country. Overall, first argument is that SMEs are the main players of the economy pushing the country ahead and CSR programs contribute their development through "direct supply chain relationships, as well as the development of legislation, and international standardization and certification... On the other hand, CSR offers opportunities for greater market access, cost savings, productivity and innovation to SMEs, as well as broader social benefits such as education and community development” [18].

Second argument for CSR in developing countries is that by doing charity, philanthropic programs or increasing social welfare in the host countries, TNCs distribute their power and do not becomes monopoly or power center, thus cannot influence decisions of the government. Profit maximization objective in itself results in concentration of economic power in one hand or several central hands, and it appears that they use their money power to make the governments do their wills [19]. Therefore conducting social programs, TNCs will not be able to become power/money center which is in favor of Developing Countries.

On the other hand, we argue that it is vice versa process that by bearing CSR programs, TNCs get more power to influence decisions of the government, since they donate a lot of money to social programs or finance some projects of the government. Consequently government depends heavily on the TNCs and if we take into consideration that some TNCs overall budget is more than developing countries, so it can be clearly understood their influence on the governments. Schwartz \& A.B. Carroll write about "opportunistic compliance" character of the TNCs, which means they seek for gaps in the legislation to be engaged with certain activities, and in developing countries they successfully find them and process their activities "within law" or "lawfully". "Corporations which decide to operate in developing nations because of less stringent environmental, employee-welfare, or consumer-protection legislation are opportunistically complying with the law" (2003).

Second drawback of CSR programs in these countries is that they allure government and society with philanthropy and consume their natural resources more easily. Indeed they have not been designed to increase the social welfare of the country, but to provide their own interests. It is clear that TNCs main purpose is to maximize their profits as much as possible for their shareholders, and we believe CSR programs are just a way going to their purposes. They operate to turn to the leaders in the development of the capitalism system.

Thirdly, the reason of their locating in the Developing countries is apparently for cheap labor force and low salary [20]. We can take Nike, Adidas and Coca-cola companies as examples which built their production process in China, Asia and poor countries of Africa. In 1998, International Labour Organization announced seven big corporates who breach human rights violently, they were sport clothes and shoes company Nike and Adidas, clothes companies H\&M, Levi Strauss, C\&A, toy producer Walt Disney and the biggest post company Otto-Verstrand. They were also revealed to pay $2 \$$ per day to the workers in the factories. The question arises here if CSR is the main external policy of the corporates in Developing Countries, then to which interests they serve to and why they do not operate effectively in these nations. Our answer is that CSR is used by corporates when they are needed and when they might serve interests of the company. The actual theoretical meaning of CSR does not mean only charity events, but it indeed means not breaching laws and human rights of the host country. Even if the TNC does not conduct any CSR programs, but obeys all the rules and pays taxes, employ people and pay high salaries to them, in itself it is a perfect CSR policy of the corporate.

\section{Conclusion}

To sum up the article, the paper did research in the hope of clarifying what advantages and disadvantages of 
CSR programs were for the TNCs and what benefits and drawbacks developing nations obtained from CSR programs of TNCs. We pointed out five advantages of CSR for TNCs in developing countries analyzed different economists ideas about this issue. In the section of arguments against CSR of TNCs, we found out four strongest arguments from M. Friedman, Davis and D. Vogel. The last part of the paper tried to look at the case from the point of developing countries, which CSR was usually designed for them. Surely there were both negative and positive sides of the CSR in their countries, such as influencing government decisions, avoiding regulations and taxes, violation of labor code, gender discrimination and so on. However, it had good sides as well, such as easing and lightening government's burden, conducting social programs and decreasing and curing social problems of the country. Also it was very beneficial for the TNCs since in competitive advantage economic system in the modern world, they needed positive image of their company more than everything. Positive image, sympathy from the society and government apparently eased their business load, extended their lifespan and made them more competitive than their rivals.

\section{References}

[1] Andrews, K.R. (1973) Can the Best Corporations Be Made Model? Harward Business Review, 51, 57-64.

[2] Archie, B. and Kareem, S.M. (2010) Business Case for Corporate Social Responsibility: A Review of Concepts, Research and Practice. International Journal of Management Reviews, 12, 85-105.

[3] Blanchard, O., Amighini, A. and Giabazzi, F. (2010) Macroeconomics: A European Perspective. Pearson Education Limited, Essex.

[4] Caroll, A. (1979) A Three-Dimensional Conceptual Model of Corporate Performance, University of Georgia, Athens.

[5] Caroll, A. (2004) Managing Ethically with Global Stakeholders: A Present and Future Challenge. Academy of Management Executive, 18, 114-120.

[6] Chuanli, W. and Gang, D. (2007) Social Responsibilities of Transnational Corporations. Frontiers of Law in China: Selected Publications from Chinese Universities, 2, 378-402.

[7] Dalshud, A. (2006) How Corporate Social Responsibility Is Defined: An Analysis of 37 Definitions. Corporate Social Responsibility and Environmental Management, 15, 1-13.

[8] Davis, K. (1967) Understanding the Social Responsibility Puzzle. Business Horizons, 10, 45-50.

[9] Davis, K. (1973) The Case for and against Business Assumption of Social Responsibilities. Academy of Management Journal, 16, 312-322. http://dx.doi.org/10.2307/255331

[10] De George, R.T. (1993) Competing with Integrity in International Business. Vol. xii, Oxford University Press, New York, $233 \mathrm{p}$.

[11] Donaldson, T. (1989) Moral Minimums for Multinationals. Ethics \& International Affairs, 3, 163-182. http://dx.doi.org/10.1111/j.1747-7093.1989.tb00217.x

[12] Epstein, E.M. (1987) The Corporate Social Policy Process: Beyond Business Ethics, Corporate Social Responsibility, and Corporate Social Responsiveness. California Management Review, 29, 99-114. http://dx.doi.org/10.2307/41165254

[13] Friedman, M. (1970) The Social Responsibility of Business Is to Increase Its Profits. The New York Times Magazine, 33, 122-126.

[14] Gumbel, P. (2004) Total Clean up. Time, 51, A10-A12.

[15] Levitt, T. (1958) The Dangers of Social Responsibility. Harwads Business Review, 36, 41-50.

[16] Melloan, G. (2004) Feeling the Muscles of the Multinationals. Wall Street Journal. http://www.wsj.com/articles/SB107335324660584300

[17] Raynard, P. and Forstater, M. (2002) Corporate Social Responsibility: Implications for Small and Medium Enterprises in Developing Countries. UNIDO.

[18] Schwartz, M. and Carroll, A. (2003) Corporate Social Responsibility: A Three-Domain Approach. Business Ethics Quarterly, 13, 503-530. http://dx.doi.org/10.5840/beq200313435

[19] Sunday, N. and Titus, E. (2006) Analysis of the Arguments for and against Corporate Social Responsibilities in Nigeria. Ebonyi State University, Abakaliki.

[20] Vogel, D. (2008) CSR Does Not Pay. www.forbes.com 


\author{
Abbreviations \\ TNC-Transnational Corporations \\ MNC-Multinational Corporations \\ CSR-Corporate Social Responsibility \\ UNCTAD-United Nations Conference on Trade and Development \\ DC-Developing Countries \\ SME-Small and Medium Enterprises \\ BP-British Petroleum
}

